People - The New Asset on the Balance Sheet 
People - The New Asset on the Balance Sheet is the second in a series of books by Joseph DiVanna and others in the Corporations in the Global Economy series. The books in this series cover a variety of topics, including thinking strategically, managing the process of a global business, technology's return on investment, corporate innovation and business molecularity. The first title is:

Strategic Thinking in Tactical Times by Joseph A. DiVanna and François Austin

Also by Joseph A. DiVanna

REDEFINING FINANCIAL SERVICES

THINKING BEYOND TECHNOLOGY

SYNCONOMY

THE FUTURE OF RETAIL BANKING 


\section{People - The New Asset on the Balance Sheet}

Joseph A. DiVanna and Jay Rogers 


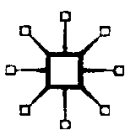

(c) Joseph A. DiVanna and Jay Rogers 2005

Softcover reprint of the hardcover 1st edition 2005 978-1-4039-3689-9 All rights reserved. No reproduction, copy or transmission of this publication may be made without written permission.

No paragraph of this publication may be reproduced, copied or transmitted save with written permission or in accordance with the provisions of the Copyright, Designs and Patents Act 1988, or under the terms of any licence permitting limited copying issued by the Copyright Licensing Agency, 90 Tottenham Court Road, London W1T 4LP.

Any person who does any unauthorized act in relation to this publication may be liable to criminal prosecution and civil claims for damages.

The authors have asserted their rights to be identified as the authors of this work in accordance with the Copyright, Designs and Patents Act 1988.

First published in 2005 by

PALGRAVE MACMILLAN

Houndmills, Basingstoke, Hampshire RG21 6XS and

175 Fifth Avenue, New York, N.Y. 10010

Companies and representatives throughout the world.

PALGRAVE MACMILLAN is the global academic imprint of the Palgrave Macmillan division of St. Martin's Press, LLC and of Palgrave Macmillan Ltd. Macmillan ${ }^{\circledR}$ is a registered trademark in the United States, United Kingdom and other countries. Palgrave is a registered trademark in the European Union and other countries.

ISBN 978-1-349-51899-9

ISBN 978-0-230-50957-3 (eBook)

DOI 10.1057/9780230509573

This book is printed on paper suitable for recycling and made from fully managed and sustained forest sources.

A catalogue record for this book is available from the British Library.

Library of Congress Cataloging-in-Publication Data

DiVanna, Joseph A.

People - the new asset on the balance sheet / Joseph A. DiVanna and Jay Rogers.

p. $\mathrm{cm}$.

Includes bibliographical references and index.

1. Human capital. 2. Productivity accounting. 3. Industrial productivity - Management. I. Rogers, Jay V., 1950- II. Title. HD 4904.7.D4988 2005

$657^{\prime} .4-\mathrm{dc} 22$

2004056750

$\begin{array}{llllllllll}10 & 9 & 8 & 7 & 6 & 5 & 4 & 3 & 2 & 1\end{array}$

$\begin{array}{llllllllll}14 & 13 & 12 & 11 & 10 & 09 & 08 & 07 & 06 & 05\end{array}$ 
To Roy Frangione an IBM veteran, who was the embodiment of a thought leader and thought partner, and whose untimely death was indeed a loss to all of us, to my wife Isabel who is always ready to comment on the many versions of the manuscript without getting grey hairs, and to my sons Frank and Leo, who are my inspiration.

JOE DIVANNA

To Lisa, who leavens the process of writing with welcome musings and merriment. JAY ROGERS 
This page intentionally left blank 


\section{Contents}

List of Figures and Tables

viii

Preamble

ix

Preface

xiii

Acknowledgements

xvii

Introduction

1 The Personalization of Value

The employee value proposition

Confusing terms: human capital, knowledge assets, intellectual capital

Rethinking work, skills and the application of talent

2 Fluidity in a Dynamic Marketplace

Education should drive the market, not follow it

All employment is temporary

Labour shortages and the new face of globalization

3 The New Balance Sheet

Qualitative metrics: a humanist approach

Quantitative measures: the bean counter's friend

The equation for valuation: notes to the financial statement

Conclusion: The Agenda for Action

Notes

Bibliography

Index 


\section{List of Figures and Tables}

\section{Figures}

I.1 Growth-decline cycle 5

$\begin{array}{lll}1.1 & \text { Employee's perceived value proposition } & 11\end{array}$

$\begin{array}{lll}1.2 & \text { The network of human capital assets } & 15\end{array}$

$\begin{array}{lll}1.3 & \text { Establishing corporate competency } & 17\end{array}$

$\begin{array}{lll}1.4 & \text { Human capital structure } & 19\end{array}$

$\begin{array}{ll}1.5 & \text { Employee value proposition }\end{array}$

1.6 Calculating the thickness of a wall 46

2.1 Mentoring model 78

$\begin{array}{ll}2.2 & \text { The continuum of experience } \\ & 81\end{array}$

3.1 Characteristics of human capital assets 118

3.2 Spencer Stuart's Human Capital Market Index 119

$\begin{array}{ll}3.3 \text { Competency development cycle } & 120\end{array}$

3.4 Corporate competency diagram 122

3.5 The composition of human capital liabilities 125

3.6 Enhancing the company reporting process 126

3.7 Educate: corporate capabilities and competencies 131

3.8 Educate: competencies diagram 131

3.9 Educate: process steps to competencies 132

3.10 Educate: employee self-assessment 135

3.11 Educate: employee self-assessment analysis 137

3.12 Educate: balance sheet and income statement 144

3.13 Educate: revenue analysis $\quad 145$

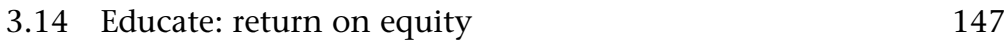

3.15 The intangible value 156

3.16 Stern Stewart \& Co.: economic value added formula 159

3.17 Human capital asset classes 161

\section{Tables}

2.1 The top ten fastest growing occupations in the USA, 2002-12

3.1 Saratoga Institute: standard metrics 


\section{Preamble}

Since the mid-nineteenth century, businesses have been hard-pressed to measure the value of tangible assets and the capital allocations required to make intangible assets produce measured return on investment. The industrial age saw a dramatic increase in the scale and complexity of obtaining raw resources such as metal ore, textiles or chemicals and then manufacturing them into finished goods. Consequently, the need for ways to track the increase in value as raw resources moved through discovery, refining, manufacturing and distribution spurred organizations to standardize accounting practices. Over time, accounting practices have matured, mirroring the process which they were designed to track. As for people, the cost of employee wages were generally considered a sufficient market in most accounting ledgers. Modern technology and growing customer sophistication in a global marketplace are acting to accelerate the steps which a firm must take to remain competitive. Unfortunately, for most corporations, the mechanisms traditionally used to measure corporate activities have not changed to reflect the new composition of the business environment. Simply, as businesses reengineer themselves and apply technology in increasingly new ways, it becomes apparent that the associated skills, knowledge and applied value of people must be reevaluated and now needs to be reflected in the mechanisms used to measure their direct and indirect contribution to each business process.

In the twentieth century, new leverage points for business came into their own. Economic capital became a critical factor driving expansion and more sophisticated international trading. Accounting standards were hard pressed to manage this sea change. New types of capital equities, exchange trading of those equities on a massive scale, international debt financing and futures markets are examples of key levers stimulating international growth in the last century. At times, that growth was interrupted by the problem of valuing the interaction among capital, assets and liabilities. Securing, borrowing, investing and settling economic obligations needed a rigorously defined system of valuation and accountability. Floating exchange rates, international settlement procedures and new accounting rules 
were defined or revised to maintain trust and market equilibrium. With the baby boom, the influx of women into the workplace and better-educated employees, business had an ample supply of talent. They could and did take employee valuations for granted.

Technology emerged as key enabler to supporting a $24 \times 7$ trading capability that scaled to handle trillions of transactions. Measuring technology's reliability and value became a prime focal point as firms sought to shorten the time between transaction and settlement, between capturing accounting data and publishing it. IT was the twoedged sword that enabled improvements in accounting capabilities while befuddling those who attempted to accurately measure its economic contribution within individual firms. In the latter part of the twentieth century, valuing and measuring a firm's technology assets and capabilities reached new levels of controversy.

Technology became an asset class that engendered both real and illusory valuations. Early debates on the valuation of IT focused on when it should be evaluated as a capital asset and when it was a business expense. IT asset driven companies went on to hit new and irrational levels of valuation (witness for one the record write-offs driven by America's most prominent Internet Service Provider, AOL). IT's value seemed no longer dependent on merely the value of the information (or the occasional knowledge) it conveyed. Conversely, today the value of IT is threatened by an explosion of misinformation (spam and viruses being two prime examples).

Literally at the heart of the valuation controversy is our subject: people. We believe the firms that seek to measure rigorously and invest in people, as capital assets, will realize significant value for their employees, customers and investors. To manage intelligently the firm's greatest assets, that is, knowledge and the applied value of people, there must be linked to business processes by quantitative and qualitative measurements. Otherwise, unrealistic valuations for technology, future cash flow, resource holdings, etc., are likely.

\section{The valuation of human capital (HC)}

This book focuses on how to measure and link people's production of information, knowledge, services and products. For our purposes, human capital and its associated value can be described as the skills, competence and capabilities that are inherently attributed to the 
members of the organization. Simply, human capital is the tacit knowledge held in people's brains. ${ }^{1}$ Although a key element of human capital is knowledge, we will not attempt during the course of this book to assign a value to the know-how of an organization. However, since we will refer to knowledge in various forms throughout this text it is perhaps best to define it in the same context as Ferguson:

An 'awareness of how the world works' created through learning, as data and information are selected, discarded, processed, synthesized and combined with existing knowledge. Explicit knowledge can be written down or described by using diagrams or mathematical expressions, and so can be readily transmitted to others. Tacit knowledge is intrinsic in human resource and cannot be readily transmitted to others. Organizational-specific knowledge is unique to a particular organization and so it is a source of potential advantage. ${ }^{2}$

People resent being defined as assets since they are not property, but living, free, resourceful, wilful, individuals. Yet clearly, they drive and are driven by two key twenty-first-century assets: information and knowledge. While objective data can be processed by binary computers, information and knowledge require human components. We borrow from traditional information theory to designate information as composed of three components, a specified sender, a specified recipient, and a message, that the latter considers relevant. The last point is critical in designating the recipient and not the sender as the ultimate determination of whether an incoming email is information or spam. The rubric of human capital (HC) then spans people and the information and knowledge they produce in the forms as diverse as hallway conversations, work processes and patents. We recognize that human capital raises the spectre of employees as indentured servants or at the extreme slaves. While information and knowledge can be bartered and sold people cannot. Our presumption is that $\mathrm{HC}$ is a legitimate and meaningful characterization if writers, employers and employees champion two fundamental principles:

1. Employees and employers share equal responsibility in openly defining mutually agreeable terms and conditions of employment. 
Either employee or employer can sever the employment relationship unilaterally, although either or both of the parties may be entitled to specified considerations as a result of the severance.

2. Employers and employees share an ongoing commitment jointly to measure and respond to progress and changes in employee, business and market performance. The dissolution of tacit lifetime employment agreements requires both employers and employees to agree on how the risk of job termination will be managed. In the twenty-first century world of work that means employers and employees have a joint obligation to agree on the key measures for individual and organizational performance. Equally important is the obligation jointly to review and agree on how the firm and the individual is progressing in relationship to agreed on metrics and goals.

We hope that both employers and employees will use this book to qualify, quantify and link how they create business value, innovate, improve productivity, and make informed choices on issues such as training, job change, job migration and rewards. 


\section{Preface}

Trying to place a value on people and their associated skills is not a new issue for corporations. In the eighteenth century, Adam Smith realized that labour was more than hours worked; John Westerman struggled to understand why Swedish shipyards needed twice as much labour as their English and Dutch counterparts. ${ }^{1}$ In Eliasson's view, English and Dutch shipyards had three distinct advantages that worked in concert to leverage the physical labour needed to construct ships: new machines, knowledge to use the machines and managers who knew how to organize work or production to capitalize on these elements as a capability. Throughout the nineteenth and twentieth centuries, technology, knowledge and management worked symbiotically, creating new products, satisfying customers and rewarding shareholders. Suddenly, during the last decade of the twentieth century, this triumvirate was reshaped as technology became the dominating factor of market differentiation. Business became obsessed with leveraging technology, for example buying more computers and using them for ever increasing business functions. The dotcom boom exacerbated this simple act of acquiring technology, because it was perceived as demonstrating to customers the firm's technological prowess. Countless corporations built websites and eCommerce capabilities regardless of customer demand, in many cases without fully understanding how technology specifically altered their products' production, distribution and perceived value to their customers. During the dotcom boom, corporations acquired technology seemingly because everyone else believed it was necessary and therefore valuable. However, after the dotcom industry's meltdown, corporations have come to the realization that two firms equipped with similar technologies often produce significantly different results. Senior management started asking questions regarding the wide variability in results. Thus at the dawn of the twenty-first century, companies are now reevaluating the use of technology as the key element in the formula for market differentiation opting to focus on technology's applied use by the individuals employed throughout the corporation. Perhaps the balance in the old triumvirate has returned. 
Corporations are quickly realizing that the competitive pressures of a rapidly globalizing business environment demand that organizations achieve higher levels of performance, innovation and customer service in all aspects of their business. In the newly forming borderless world of commerce, businesses large and small are suddenly appreciating technology's new role, i.e. simply to provide the firm with a specific means to generate value to their customers while the human resources of the organization give the company its market differentiation. Examining a large number of corporations in a wide variety of geographies, one can recognize that a company's value proposition to its customers is comprised of three fundamental factors: the rate at which technology can be absorbed or deployed by the organization; the depth at which the firm can apply technology to the business processes; and the abilities of the talent within the firm to optimize, streamline or redesign the fundamental business processes in direct response to customer demand. Within a corporation, various combinations of these three factors form competencies.

Assessing the relative value of people and their combined abilities has plagued managers, businesses and academics for decades. In the United Kingdom, the need to understand the fundamental issue of human capital and the relationship between performance, competency and value generation led to the formation of the Taskforce on Human Capital Management by the Secretary of State for Trade and Industry in January $2003 .^{2}$ The mandate for this taskforce is to analyse and address key questions on the effectivity of human capital management and the use of performance indicators throughout an organization. More interestingly, the taskforce raises the fundamental question: can performance indicators be standardized across industries to provide investors, market analysts and government agencies with a relative measure which assess a firm's brainpower? Previously human resource (HR) practioners have attempted to address this issue by applying quantitative measures to specific aspects of a person's abilities or to a highly specialized group. These efforts resulted in approaches such as function point analysis ${ }^{3}$ for software development groups within the firm and mechanisms such as skills inventories. In many cases, these efforts brought some semblance of order to areas of the firm that seemed chaotic to management. For the most part, these attempts at valuing human resource capabilities have fallen short of corporate expectations because they failed to incorporate key 
variables such as creativity, adaptability, innovation, morals, ethics, people skills and the aggregate power of teamwork.

Recent work to place measurement into perspective, created by scholars such as Kaplan and Norton in The Balanced Scorecard and Jac Fitz-enz in Human Capital Branding, have resulted in improved information, supplying a new set of tools to senior managers. In this book, we offer several possible approaches for organizations to begin their journey into the topic of human capital management. Here, we offer qualitative and quantitative frameworks in which to establish a value proposition for measuring, monitoring and rewarding what has been traditionally thought of as 'softer components' of corporate competency as a convenient starting point. The central argument is that the value of human capital is not found in any qualitative or quantitative measures placed on individuals, but in the value generated to customers by the combined efforts of many diverse talents which are more difficult to quantify. For example, how does one place a quantitative measurement on the personal chemistry of a management team, which is often a gut-feel parameter used by venture capitalists to evaluate the investment risk in a start-up company? Similarly, how can five people in one corporate environment achieve one level of productivity and the same five people transferred to a different corporate environment perform marginally better or worse? Measuring individuals is designed to be objective; it is a tool to understand better the environment in which people perform and how to help them excel.

However, establishing the value for individuals is only half the equation; any generated metrics of human value is relative to management's ability to harness, focus and direct not only the production of the company, but also the continual growth of the firm's intellectual capital. Corporations professing that 'people are their greatest asset' call for a framework for valuing people and an opportunity to lead global companies into new levels of human capital management. It is with the mindset that there is no one global solution to the problem of valuing human capital that we begin this journey into the long-standing debate on measuring the value of what human beings produce. Perhaps more importantly, our journey begins with understanding how measurement in a meaningful context provides an indicator to the untapped potential of what individuals can produce in a given environment or under a specific organizational 
structure. Unfortunately, our traditional measures of corporate performance found in the firm's annual report do not portray accurately to investors a definitive picture of the potential of the corporation's intangible assets (for example, people and their associated skills). For example, the absence of standard measurements has led venture capitalists to devise a more empirical means to predict the future performance of a management team before making substantial investments in a start-up corporation. During the due diligent phase of the relationship, the venture capitalists spend time to get to know the talent of the management team. Venture capitalists use empirical data, in conjunction with their experience and knowledge, to observe the behaviour of a team, and this guides them in thier valuation process. Needless to say, this is a time-consuming and labour-intensive process which is not practical across large-scale organizations. Dickson notes that in many industries such as the services and high-valueadded manufacturing sectors, the skills, knowledge and loyalty of the firm's employees have often made the difference between success and failure. ${ }^{4}$ Recognizing the potential deficiency of any global or national standard for reporting the value of human capital, this book examines a variety of approaches being used by corporations to address this issue. The primary approach used here reflects multiple corporations using a variety of methods which have, in turn, been adapted for several small to medium-sized enterprises (SMEs) to address the problem of talent management. The names of some of the companies have remained confidential as per their request. 


\section{Acknowledgements}

As individuals, we come to realize that our journey into the world of human capital started many years before we realized the significance of the part people play in the production of business. For some of us a single individual will invest a small part of their human capital in us which over time will yield significant returns. Thus a chance exposure to Richard (Bucky) Buckminster Fuller, in a lecture room at Hood College in 1978, begins this journey to understand the value that people bring to an organization. Bucky changed forever my perspective on the world around me. His advice to me (and everyone on the planet) was simple - investigate how things work and then challenge why they came to be. One consistent message that was at the heart of Bucky's motivation was straightforward: 'doing more with less'. This uncomplicated inspiration was akin to the rallying cry for reengineering. Michael Hammer and Jim Champy's Reengineering the Corporation put forth a straightforward message; business had developed for many years with technology contributing to enhance productivity and at the same time limiting how organizations accomplished work. As technology advanced it was time for a radical rethinking of the processes used by corporations to achieve value.

These simple mantras became for me over the years a lens through which to view the challenges of business, becoming more valuable as we begin to address the changing landscape of business in the twenty-first century. In October 1994, while working at CSC Index, I was asked to fly to Princeton, New Jersey to participate in a workshop called 'Tango', led by Karl Erik Sveiby. In a large conference room, consultants, practioners and academics engaged in a board game designed to emulate the acquisition of talent, the applied use of the talent to projects and the relationship between investing in talent and talent retention.

Upon returning to my office in Boston, I read Sveiby's book The Invisible Balance Sheet which not only made sense, it also made me astonished that companies were not rushing to adopt the framework or at least adapt it in some way. Bucky's lens and Sveiby's long-underused book served as inspiration and basis for this book. People - The 
New Asset on the Balance Sheet builds on the work of Jac Fitz-enz and others in an attempt to take the subject of human capital management and view it from the perspective of a non-human relations professional. We tried to look at the issues involved through the eyes of a senior manager who must make decisions that span the corporate enterprise while taking into consideration new thinking from the field of human resource management.

Several individuals deserve acknowledgement for their contribution, direct or indirect, to this book. We would like to thank David Thomas, Pamela Freeman and Katie Latimer from CRAC Cambridge for their support in organizing the CRAC AGM on the topic of People - The New Asset on the Balance Sheet. We would also like to acknowledge Stuart Bradley from Corven Partners for many interesting discussions on human resources, and Nina Komissarova of TROIKA Dialog, for all her help in my research during a brief visit to Moscow. A big thank you to Deborah Knowles from the Westminster Business School, Dr Andrew Bottomley (BHR Associates Ltd) and Tom Serpell (Obsidian Consulting) for all their comments on this book.

I would like to extend a special thanks to Saleh Al-Jewain of the Arabian Society for Human Resource Management for his unsurpassed hospitality and in-depth discussions on the challenges of human resources in the Middle East. Opening my eyes to the complex multicultural issues of Transnational Human Resources was Mohammed Al-Khalfan from Saudi Aramco and Aahad Osman-Gani of the Nanyang Business School in Singapore.

Once again I would like to express my most sincere appreciation to the provost and fellows of King's College, Cambridge, for their continued support of my research.

Finally, I would like to thank Isabel DiVanna for all her help in typing, editing and ensuring that the argument of this book 'holds water'.

JoSEPH A. DiVANNA 